\title{
USING JUMBLED LETTERS TO IMPROVE STUDENTS VOCABULARY MASTERY
}

\author{
Sri Wahyuni ${ }^{1,}$ Ali Wira Rahman ${ }^{2}$ \\ ${ }^{12}$ University of Muhammadiyah Parepare, Indonesia
}

\begin{abstract}
Vocabulary considered one of the important things to learn for students, the vocabulary is basic thing that students must be mastered in foreign language lessons, especially in English. Without vocabulary students will have difficulty in mastering skills in English such as writing, reading, listening and speaking. Therefore, it is very important to find out the solution to enhance students' vocabulary. The objective of the research is to find out whether or not using Jumbled letters can improve the students vocabulary of the tenth grade students in MAN 2 Barru and to find out whether or not using Crossword puzzle can improve the students vocabulary of the tenth grade students in MAN 2 Barru. This research applied quasi-experimental group design with two groups experimental and control class. The population of this research was the tenth grade students of MAN 2 Barru in academic year 2018/2019. The Total sample of the research was taken by using clustering random sampling which consisted of 141 students. From two classes taken from the population of the tenth grade students of MAN 2 Barru, X MIA 1 as the experimental class consisted 29 students and X MIA 3 as the control class that consisted 29 students. The result of the data analysis showed that there was a significant difference of students' vocabulary before and after teaching vocabulary through jumbled word letters. The value of $t$-test pre-test 2.09 was higher than t-table 2.000, and the value of post-test 4.62 was higher than $t$-table 2.000, at the level significance $a=0.05$ and degree of freedom $(d f)=56$. It can be concluded that jumbled word letters can enhance the vocabulary of the tenth grade students' of MAN 2 Barru
\end{abstract}

Keywords: Jumbled Letters, Vocabulary.

\section{INTRODUCTION}

Vocabulary is the most fundamental thing that must be mastered by students in learning English which is a foreign language especially in Indonesia. How students can express a language if they are not understand the vocabulary of the language. Some experts such as Mehta (2009) states that "vocabulary is the first and foremost important step in language acquisition". It means in learning a foreign language the most important thing to do is master the vocabulary of the 
language itself. Furthermore, Alqahtani (2015) states that "Vocabulary learning is an essential part in foreign language learning as the meanings of new words are very often emphasized, whether in books or in classrooms. It is also central to language teaching and is of paramount importance to a language learner". So, vocabulary is the knowledge of words and their meanings and without establishing a strong vocabulary base first, comprehension and use of foreign language will not be achieved.

Based on the observed in the tenth grade students of MAN 2 Barru, there are several causes behind the researchers doing this research, including: Firstly, the lack of motivation of students in learning English and argue that English is difficult. Secondly, most of the students when learn English vocabulary is memorizing. So, it is easier to forget it. Third, after the researchers conducted a test at the time of observation that aims to see the students vocabulary mastery and found out that the average score of the students only get 54.90 and the value is included in the poor category. This condition also can be caused by technique that used in teaching process. The teachers try to apply an attractive ways in teaching process to get students' attention to learn. One of them is using jumble letters, it can stimulate and entertaint the students and also helps the teacher to create the situation in which language is useful and meaningful.

In previous research, Irfan (2013) and Irmawaty (2008) they are used jumbled word letters to increase or improve the students English vocabularies. But, the concept that they used most similar. They only specify a few words whose letters have been randomized and then give instruction the students to determine the correct random letters. So the conclusion is the stundents only get some new vocabularies whose numbers have been predetermined by the researcher.

Then, to overcome the problems, the researcher is expected to develop the teaching technique by using jumble letters with a few modification. The concept will be applied in this study is the researcher give a words that already jumbled and then the students try to rearrange the words and find out the main word. After found the main word, the students are instructed to find new words that can be formed from the main word. So, from one word the students get some new words. By these activities, jumbled letters is expected to help students to improve their English vocabulary mastery.

There are many explanations of vocabulary which stated by some researchers and experts. According to Crookall (2015:4) stated that vocabulary does not clearly teach in most language classes and students are expected to obtain their vocabulary without the guidance of others. Furthermore Palayukan (2015:10) stated that vocabulary is a main component of language competence and offers much of the principles for how well learners speak, listen, read, and write". Simply, based on Hackman (2008:3) stated that vocabulary is more than list of words, and although the size of one's vocabulary matters, it's knowing how to use in which matters most. 
According to Nadle (1954) stated that jumble is a word puzzle in which a player is given a set of letters which, when arranged in the correct order, give the un-jumbled word. A simple example would be the set of letters "lbujme", which can then be arranged to spell "jumble". Also, Pettigrew (2001) stated that the jumbled letter is a word puzzle in which a player is given a set of letters which must be arranged in the correct order that have meaning. However, according to Ismail (2004:14) stated that jumbled letter is one of technique effective for students, because from the jumble letter would stimulate the students to open their dictionary. They would found new word and if they found self, it would easier to memorize.

\section{METHODOLOGY}

The research method that the researcher applied was quasi-experimental design which involved two classes with different treatment, namely experimental class and control class. Whereas the experimental class received a treatment by using Jumbled letters while the control was treated through Crossword puzzle. The population of the research was the tenth grade student of MAN 2 Barru, The total numbers of population are 141 student. Which experimental class consisted of 29 students and control class consisted of 29 students, therefore the total numbers of samples were 58 students. In experimental class, the researcher will explain and teaching by using jumbled letters in the classroom and then ask the students to rearrange the word to the correct word. Based on the arranged word, the students find the new words and give categories from each word. Meanwhile in control class, the researcher would explain and teaching by using crossword puzzle game in the classroom and ask the students to fill the crossword puzzle based on the questions.

\section{FINDINGS}

After doing the research, the researcher found some findings. First, the researcher found that most of the students'score of experimental class is presented before giving treatment in vocabulary the students were categorized none of them in very good and good classification, $5(17,24 \%)$ students were in fair classification, $24(82,76 \%)$ students were in poor classification. After giving the treatment, the achievement of the students was categorized good. It means that the students' vocabulary mastery using jumbled letters had improved but not significant. It reveals that after giving treatment of 29 students were in good classification, $5(17,24 \%)$ students were in good classification, $22(75,86 \%)$ students were in fair classification, and $2(6,90 \%)$ students were in poor classification.

Second the researcher found that the mean score of the 29 students improves from 49.27 in pretest to 68.86 in posttest, the value of median improve from 49 in pretest to 68 in posttest, the value of mode improve from 49 in pretest to 68 in posttest, the standard deviation decreased from 10.06 in pretest to 7.69 in posttest, the minimum score improve from 23 in pretest to 70 in posttest and the 
maximum score improve from 70 in pretest to 87 in posttest. The total score is 1997.

Third, the researcher found the gain score of experimental class (19.59) is higher than mean score of control class (17.31). Based on this result, it can be concluded that achievement in experimental class was more significant than control class. Therefore, the students who were using by Jumbled letters showed more significant difference in vocabulary mastery than students who were taught by using Crossword puzzle.

The last the researcher found that the t-test. After analyzing the data by using the test formula, the result of t-test value (4.62) is higher than t-table value is (2.000). It indicates that $\mathrm{H}_{1}$ was accepted and $\mathrm{H}_{0}$ was rejected and the students who were taught use jumbled word letters are better than the students who were taught use crossword puzzle.

\section{DISCUSSION}

In the pre-test, the researcher found that most of students' vocabulary was still poor. It was proved by mean score of the students in the experimental class was only 49.27 with standard deviation 10.06 . While, in the control class the mean score of the students was 44.14 with standard deviation 10.10 . It means that the students' vocabulary both in experimental and control class before gave treatment was classified as poor (Permendikbud,2013). It was caused the students were difficult to understand the vocabulary and their vocabulary still lacking.

In solving this case, the researcher had any solution to solve by giving treatment. One of ways to improved vocabulary is the using jumbled letters. Jumbled letters is a strategy with rules, a goal an element of fun and is useful to present vocabulary to students. Teaching vocabulary through jumbled letters will make the students be easy to memorize the words that found. The students will also be fun in studying.

There were two classes in this research namely experimental class and control class. The researcher gave treatment four meeting in both classes. In the experimental class, the researcher applied jumbled word letters. In experimental class, the researcher explain about the material such as introduction self and congratulating expressions. After that the researcher divided the students into four groups. The researcher asked every group to read the text and discussion about the text. After finish, the researcher give the students jumbled letters worksheet and the students have to answer the worksheet. In control class the researcher applied the crossword puzzle. The researcher gave similar topics to the students in each meeting. Then, the researcher give the students crossword puzzle sheet and the students have to answer the questions.

After giving treatment, the researcher gave post-test to the students in both experimental class and control class. The researcher found that the mean score of the students in experimental class was 68.86 while in control class, the mean score of the students was 61.45. Based on the (Permendikbud, 2013) it could be classified as good in experimental class and good in control class, but the 
mean score in experimental class higher than in control class. It showed that there was an improvement of the students' vocabulary. While the result of the standard deviation in the experimental class was 10.06 in the pre-test to 7.69 in post-test. The standard deviation of the students in the control class was 10.10 in the pretest to 6.97 in post-test. It means that all the students both in experimental class and control class understood the material well.

In testing hypothesis, after used the t-test formula, the result computation of t-test was 2.09 for pre-test and 2.000 for post-test. If we consulted with t-table value with degree of freedom (df) $\mathrm{N}_{1}+\mathrm{N}_{2}-2$ were significantly different. This indicated that the null hypothesis $\left(\mathrm{H}_{0}\right)$ is rejected and alternative hypothesis $\left(\mathrm{H}_{1}\right)$ is accepted because t-test value in post-test (4.62) was higher than t-table value (2.000). Therefore, the researcher concluded that teaching vocabulary applied jumbled letters can improve the students' vocabulary of the tenth grade students in MAN 2 Barru.

This research supports some previous research findings. The first is con ducted by Irmawaty (2008) she also used jumbled letter to improve the student vocabulary mastery. She stated that jumbled letters is a strategy in teaching and learning vocabulary process. Her research found the scores of pretest 51.97 and scores of posttest 78.74. Based on the data, the researcher concluded that by using Jumble letters was effective to improve the vocabulary of the students. The similarity with this research are the same skill of vocabulary, used quasiexperimental design and used group in teaching process. While, the differences are in materials in the classroom, process applied strategy in the classroom, the total number of students and this research strategy applied in Elementary school.

Irfan E.M. (2013) in his research also used jumbled letters to enhance the students vocabulary. His research find out the mean scores before giving treatment was 49.6 and after giving treatment the mean score was 79.0. It indicates that after teaching by using Jumbled letter was effective to improve the student's vocabulary mastery because jumbled letters can help students memorizing the word, increasing students' motivation in learning and encourage the students socializing. The similarity with this research are also the same skill of vocabulary, and used quasi-experimental design. While the differences are in the treatment when teaching process, in irfan's research only gave the student words that already jumbled and the students have to rearrange to the correct word but in this research, the researcher gave the students to rearrange the word to correct word as main word. After the students arranged the word, the students have to find the new words from the main word. However, the students got some new words from one words. The other differences are materials teaching in the classroom, the total number of students in the classroom and this research strategy applied in Junior high school.

The previous findings have a relationship with this research; almost all of them used jumbled word letters as a strategy to improve the students' vocabulary and used quasi-experimental group design in their research. Although the final value found is different, but the use of this strategy can be said effective in 
improving students vocabulary. However, the researcher can take a conclusion that jumbled word letters gives effect to improve the students' vocabulary. Before the strategy applied, the students seemed to be difficult to memorizing vocabulary. After the strategy applied the students easy to memorizing vocabulary and can improve their vocabulary mastery especially in English vocabulary.

\section{CONCLUSION}

Based on the findings and discussion of the study, the result of the data analysis shows that the students' vocabulary improved but not significant. It was showed by the mean score of pre-test (49.27) and the post-test (68.86) while, based on KKM Depdiknas the average score of students must be at 75 . It shows that there were the differences the students' vocabulary at the tenth grade students of MAN 2 Barru after and before teach apply jumbled letters. After analyzing the data by using the test formula, the result of t-test value (4.62) is higher than t-table value is (2.000). It indicates that $\mathrm{H}_{1}$ was accepted and $\mathrm{H}_{0}$ was rejected and the students who were taught use jumbled word letters are better than the students who were taught use crossword puzzle.

On the findings and previous chapter, the researcher concluded that jumbled word letter is one of the good strategy because it can be comes a problem solving for handle the problem of students in vocabulary at MAN 2 Barru. It was showed in the findings chapter, vocabulary score of the students are improved by using jumbled letters.

\section{REFERENCE}

Alqahtani. 2015. The Importance of Vocabulary in Language Learning and How to be Teach. International Journal of Teaching and Education. DOI: 10.20472/TE.2015.3.3.002

Crookall, David, Rebecca Oxford. (n.d) Vocabulary Learning: A Critical Analysis of Techniques, Retrivied April 11, 2018, from http://files.eric.ed.gov/fulltext/EJ407134.pdf.

Hackman, Sue. 2008. Teaching Effective Vocabulary. Retrieved from http://webarchive.nationalarchives.gov.uk/20130401151715/http://w ww.education.gov.uk/publications/eOrderingDownload/TEV_A4.pd f. on March 14, 2018,

Irfan, E.M. 2013. Increasing Vocabulary Mastery of The First Years Students of SMP Negeri 1 Balusu Through Jumbled Letter. Unpublished Thesis: Universitas Muhammadiyah Parepare.

Irmawaty. 2008. Using Jumble Letters in Teaching English Vocabulary to The Fifth Grade Students of SD Negeri 8 Parepare. Skripsi tidak diterbitkan. Parepare: Universitas Muhammadiyah Parepare.

Ismail. 2005. Using Jumble Letters in Teaching English Vocabulary to the Second Year Students of SMP Negeri 2 Watang Pulu. Unpublished Thesis. Parepare FKIP UMPAR. 
Mehta, K.M. 2009. Vocabulary Teaching:Effective Techniqueologies. The Internet TESL Journal, Vol. XV, No. 3, 2009. Available at http://iteslj.org/Techniques/Mehta-Vocabulary.html. [accessed $11 / 04 / 18]$.

Nadle. Martin. 1954. Definition of Jumble. (http://en,wilkipedia.org/wiki/jumble).

Palayukan, Hera. 2015. Improving the Vocabulary Mastery of the Seventh Year Students of SMP Negeri 2 Parepare Through Pictures and Students Active Strategy. Skripsi tidak diterbitkan. Parepare: Universitas Muhammadiyah Parepare.

Peraturan Menteri Pendidikan dan Kebudayaan. 2013. Peraturan Tentang Penilaian Perkembangan Anak Didik. Jakarta: Permendikbud

Pettigrew, Joseph. 2001. Technique in Teaaching Vocabulary. On line (http://people.bu.edu/jpettigr/Articleandpresentations/Vocabulary.htm 1).UNM. 